\title{
SIKAP ETIS KRISTEN TERHADAP PERCERAIAN MENURUT MARKUS 10:9
}

\author{
Jefry Lodewyck
}

PENDAHULUAN

\begin{abstract}
Allah menjadian ciptaanNya di hari pertama sampai ke lima dengan status 'baik' (Kejadian 1:1-25) namun menjadi berbeda ketika sampai pada penciptaan hari ke enam yakni dengan status 'sungguh amat baik' (Kejadian 1:31). Bagi Allah ciptaanNya yang bernama manusia memang 'sungguh amat baik' karena memang menurut gambar Allah diciptakanNya dia laki-laki dan menurut gambar Allah juga diciptakanNya dia perempuan (Kejadian 1:27).Allah juga memberkati dan memberikan perintah untuk mereka beranak cucu dan bertambah banyak, penuhi dan taklukan bumi, berkuasa atas ikanikan di laut dan burung-burung di udara dan atas segala binatang yang merayap di bumi (Kejadian 1:29). Manusia itu, Adam memberi nama Hawa kepada isterinya, sebab dialah yang menjadi ibu semua yang hidup (Kejadian 3:20). Adam bersetubuh dengan isterinya, lalu perempuan itu melahirkan seorang anak laki-laki dan menamainya Seb, sebab katanya :"Allah telah mengaruniakan kepadaku anak yang lain sebagai ganti Habel; sebab Kain telah dibunuhnya (Kejadian 4:25). Tidak ada persoalan dalam kehidupan rumah tangga Adam dan Hawa yang berkaitan dengan kasus perceraian.

Kata cerai mulailah muncul di dalam Imamat 21:7 dalam rangka mengatur tata kelola kehidupan para imam."Janganlah mereka mengambil seorang perempuan sundal atau perempuan yang sudah dirusak kesuciannya atau seorang perempuan yang telah diceraikan oleh suaminya, karena imam itu kudus bagi Allah". Imam dilarang menikah dengan wanita yang tunasusila atau bahkan yang telah diceraikan suaminya. Mereka hanya boleh menikah dengan perawan atau janda para imam yang lain (Imamat 21:13-15; Yehezkiel 44:22). Melalui hukum ini Allah menyatakan bahwa pemimpin rohani-Nya diharapkan menjadi teladan dari norman-norma tertinggi Allah bagi pernikahan dan keluarga.Di dalam PB Allah menuntut agar laki-laki harus merupakan contoh kesetiaan kepada istri dan keluarganya supaya dapat dipilih untuk jabatan penilik jemaat. ${ }^{1}$

Fakta dalam kehidupan Kristen tentang perceraian semakin marak terjadi.Ruth Scafer berpendapat bahwa kegagalan hubungan suami-istri yang diikuti perceraian adalah salah satu dari sekian banyak realitas yang terjadi
\end{abstract}

1 https://alkitab.sabda.org/commentary.php?book=3\&chapter=21\&verse=7 
dalam kehidupan manusia. Yang penting, membedakan antara kedua fenomena itu : Keinginan seorang istri atau seorang suami untuk bercerai adalah akibat dari kegagalan hubungan di antara mereka dalam aspek yang sangat dasariah, bukan sebaliknya 'kegagalan hubungan suami istri sebab keinginan untuk bercerai. $^{2}$

Mekanisme perceraian juga diatur oleh undang-undang.Dasar hukum proses perceraian di Indonesia adalah UU No.1 tahun 1974 tentang Perkawinan dan Peraturan Pemerintah Nomor 9 Tahun 1975. Berdasarkan UU tersebut, dimungkinkan salah satu pihak, yaitu suami atau istri melakukan gugatan perceraian. Walaupun demikian, ada pembeda antara penganut agama islam dan diluar islam dalam soal perceraian ini. Pasangan suami-istri Muslim dapat bercerai dengan didahului oleh permohonan talak oleh suami atau gugatan cerai oleh istri yang didaftarkan pada pengadilan agama.Untuk pasangan non-Muslim dapat bercerai dengan mengajukan gugatan cerai (baik suami maupun istri) melalui pengadilan negeri. ${ }^{3}$

Menteri Agama Lukman Hakim Saifudin prihatin angka perceraian meningkat setiap tahun, menyebut pergeseran makna dan nilai mengenai pernikahan dan perceraian sebagai salah satu factor pemicunya. ${ }^{4}$

\section{Pengertian Perceraian Secara Umum}

Secara umum perceraian adalah perpisahan antara suami dan istri.Kata "perceraian" berasal dari kata "cerai" yang berarti pisah, putus hubungan sebagai suami istri. ${ }^{5}$ Terkait dengan perceraian, Wikipedia mengartikannya bahwa perceraian adalah berakhirnya suatu pernikahan saat kedua pasangan tak ingin melanjutkan kehidupan pernikahannya. ${ }^{6}$ Selama perceraian, pasangan tersebut harus memutuskan bagaimana membagi harta mereka yang diperoleh selama pernikahan seperti rumah, mobil, perabotan atau kontrak dan bagaimana mereka menerima biaya dan kewajiban merawat anak-anak mereka. ${ }^{7}$ Belajarpsikologi.com mengartikan perceraian adalah cerai hidup antara pasangan suami istri sebagai akibat dari kegagalan obligasi peran masing-masing.Dalam hal ini perceraian dilihat sebagai akhir dari suatu ketidakstabilan perkawinan dimana pasangan suami istri kemudian hidup terpisah dan secara resmi diakui oleh hukum yang berlaku. ${ }^{8}$ Perceraian merupakan terputusnya keluarga karena salah satu atau kedua pasangan

\footnotetext{
Ruth Schafer, Bercerai Boleh atau Tidak?(Jakarta: Gunung Mulia, 2017), 1. https://pengacaraperceraian.xyz/proses-perceraian-berdasarkan-hukum-di-indonesia/ Wartakota.tribunnews.com Kbbi.web.id/cerai https://id.m.wikipedia.org/wiki/Perceraian Ibid., https://belajarpsikologi.com/pengertian-perceraian/
} 
memutuskan untuk saling meninggalkan sehingga mereka berhenti melakukan kewajibannya sebagai suami istri. ${ }^{9}$

Ada yang disebut cerai hidup yaitu karena tidak cocok satu sama lain, sedangkan cerai mati karena salah satu pasangan meninggal. ${ }^{10}$ Faktor penyebab perceraian antara lain adalah sebagai berikut : Ketidak harmonisan rumah tangga - alasan tersebut adalah alasan yang paling kerap dikemukakan oleh pasangan suami-istri yang akan bercerai. Ketidakharmonisan bisa disebabkan oleh berbagai hal antara lain, krisis keuangan, krisis akhlak, dan adanya orang ketiga. Dengan kata lain, istilah keharmonisan adalah terlalu umum sehingga memerlukan perincian yang lebih detail. ${ }^{11}$ Selain itu krisis moral dan akhlak, perzinaan, pernikahan tanpa cinta, adanya masalah-masalah dalam perkawinan itu juga menjadi salah penyebabnya.Dampaknya seing menimbulkan tekanan batin bagi tiap pasangan tersebut.Anak-anak yang terlahir dari pernikahan mereka juga bisa merasakan sedih bila orangtua mereka bercerai.Namun, banyak sumber daya yang bisa membantu orang yang bercerai, seperti keluarga besar, teman-teman, terapi, konsultan, buku, dan DVD. ${ }^{12}$

\section{Perspektif Perjanjian Lama}

Dalam Perjanjian Lama "perceraian" dipakai dalam Alkitab Terjemahan Baru Indonesia untuk menterjemahkan banyak kata yang artinya perpisahan, ketidakharmonisan, dll. Dalam teks-teks Perjanjian Lama soal perceraian jarang sekali disinggung. Walaupun jarang disinggung dengan tegas Imamat 21:7 membuat tata kelola tentang kudusnya hidup imam.

Dalam bahasa Ibrani kata yang diterjemahkan "perceraian" adalah dari kata "keritut": "perceraian". Dalam bahasa Akkad berasal dari kata kerja "karatu" artinya "to cut off" dan bentuk kata kerja sifatnya: "kartu" artinya "cut up", yang berpadanan dengan kata "to bring to an end". Arti lain adalah "cut to down" (1 Raj. 5:20).Kata-kata itu tidak hanya berhenti disitu, tetapi lebih dalam lagi yaitu berkaitan dengan "perjanjian" dan inilah yang lebih penting. Kata keritut hanya muncul empat kali dalam Perjanjian Lama, yaitu Ulangan 24:1,3; Yesaya 50:1; dan Yeremia 3:8.

Dalam LXX diterjemahkan: "apostasio". KJV: divorcement; RSV: divorce. Penggunaan kata ini menunjuk pada sebuah ikatan resmi (sah) yang kemudian di akhiri atau diputuskan dengan berbagai alas an konkrit maupun abstrak karena sudah bosan atau tidak suka lagi. Kata di atas juga diterjemahkan dengan "perceraian" yang sah karena disertakan dengan adanya

9 Ibid.

10 https://id.m.wikipedia.org/wiki/Perceraian

11 Ibid.

12 Ibid., 
surat cerai sebagai persyaratan resmi dan surat cerai adalah sebagai bukti bahwa ia boleh menikah (kawin) lagi dengan wanita lain. Inilah yang terjadi pada bangsa-bangsa non-Israel, sedangkan di dalam komunitas Israel sendiri seorang suami tidak bisa sembarang atau semaunya menceraikan isterinya dengan tanpa alasan atau bukti-bukti yang mendukung kuat.Namun sedikit banyak pengaruh dari bangsa-bangsa sekitar juga masuk.

Dalam Matius 19:8 Yesus berkata bahwa Musa 'mengijinkan' perceraian, hanya karena ketegaran hati umat Israel. Artinya, Musa tidak memerintahkan perceraian, tetapi mengatur praktik hidup yang nyata ada, dan bentuk hukum dalam Ulangan 24:1-4 sebaiknya dipahami dalam pengertian ini.Dalam ayat 4 memuat peraturan yang nyata itu. Bagaimanapun terjemahannya dari bagian ini dapat disimpulkan bahwa perceraian dipraktikkan, dan semacam perjanjian diberikan kepada si istri, kemudian sang istri ini bebas menikah lagi. ${ }^{13}$

Alasan-alasan perceraian di sini diberikan dalam kaidah-kaidah umum, sehingga tafsiran yang tepat dan pasti tak dapat diberikan.Suami mendapati 'sesuatu yang tidak senonoh' pada istrinya.Kata-kata Ibrani 'erwat davar (harfiah,'sesuatu yang telanjang'), terdapat hanya sekali lagi bagaikan ungkapan dalam Ulangan 23:14. Tidak lama sebelum zaman Kristus sekolah Syammai menafsirkan ungkapan itu hanya sebagai ketidaksetiaan, tetapi sekolah Hillel memperluas artinya menjadi sesuatu yang tidak menyenangkan bagi suami.Perlu kita ingat, bahwa Musa disini bukanlah hendak menyatakan dasar-dasar perceraian, tetapi menerima perceraian itu sebagai fakta nyata. ${ }^{14}$

Ada dua hal yang menyebabkan perceraian dilarang: pertama, jika seorang mengajukan tuduhan palsu terhadap istrinya, bahwa sebelum pernikahan mereka, istri itu sudah melakukan persetubuhan (Ulangan 22:1319); kedua, jika seorang laki-laki bersetubuh dengan seorang perempuan, dan bapak perempuan itu memaksa laki-laki itu kawin dengan anaknya (Ulangan 22:28-29; Kel.22:16-17). ${ }^{15}$

Ada dua kekecualian dan yang mendesak perceraian dilakukan. Kekecualian itu ialah orang-orang Yahudi buangan yang kembali dari pembuangan telah kawin dengan perempuan non-Yahudi (Ezr.910;Neh.13:23). Dalam Mal.2:10-16 ada yang menceraikan istrinya sekalipun orang Yahudi, supaya bisa kawin dengan perempuan non-Yahudi. ${ }^{16}$

13 Bnd. J.D.Douglas, Ensiklopedi Alkitab Masa Kini Jilid 2, 157.

14 Bnd. J.D.Douglas, Ensiklopedi Alkitab Masa Kini Jilid 2, 157.

15 Ibid.,

16 Ibid., 


\section{Perceraian Dalam Perspektif Perjanjian Baru}

Dalam Perjanjian Baru, ada tiga istilah yang dipakai untuk menjelaskan tentang "perceraian".

Pertama kata Yunani apostasion.Pelafalan ap-os-tas'-ee-on.Asal mula neuter of a (presumed) adj. from a derivative of 868.Jenis $\mathrm{n} n$ (noun neuter).Dalam TB 'surat cerai'. Dalam AV 'divorcement, writing of divorcement. Definisi divorce, repudiation, a bill of divorce. Neuter of a (presumed) adjective from a derivative of 868; properly, something separative, i.e. (specially) divorce:- (writing of) divorcement.

Kedua kata Yunani dialuo.Pelafalan dee-al-oo'-o.Asal mula from 1223 and 3089.Jenis v (verb). Dalam TB 'cerai-berailah'. Dalam AV 'scatter'.Definisi menghancurkan, mencerai beraikan, to dissolve.

Ketiga kata Yunani diaskorpizo.Pelafalan dee-as-kor-pid'-zo.Asal mula from 1223 and 4650.Jenis v (verb). Dalam TB 'cerai berailah', 'aku menanam', 'akan tercerai berai', 'memboroskan', 'menanam', 'tercerai-berai', 'menghamburkan', 'mencerai beraikan', 'yang tercerai berai'.

Ada larangan Yesus tersebut dalam Perjanjian Baru yakni di dalam 1 Korintus 7:10,11c; Markus 10:6-9; Matius 19:4b,5b-6. Ditambah perkataan Yesus yang melarang perceraian secara implicit : Lukas 18:1; Matius 5:32; Markus 10:11; Matius 19:9.

\section{Konsep Perceraian Pada Zaman Klasik}

\section{Konsep Romawi}

"Rumah" pada zaman Romawi klasik merupakan system yang sangat kompleks, hubungan suami-istri hanya salah satu relasi antara relasi lain yang di anggap penting. ${ }^{17}$ Pater Familias - secara harafiah "ayah keluarga", tetapi yang sebenarnya dimaksud adalah "kepala rumah tangga", yaitu laki-laki tertua yang berkedudukan dalam keluarga - berkuasa penuh atas istri, anak, dan budak. ${ }^{18}$ Di kota yang sekaligus pusat kebudayaan di seluruh Kekaisaran Romawi, keluarga dari lapisan masyarakat elit yang mendiami rumah tangga sedemikian. Namun, misalnya hanya presentase sangat minim dari penduduk Palestina pada abad pertama Masehi yang cukup kaya sehingga mampu mendirikan rumah tangga besar yang demikian. ${ }^{19}$ S.Guijarro menyangka tidak lebih dari sepuluh persen dari penduduk Galilea pada abad pertama Masehi mendiami kompleks perumahan dengan halaman dan fasilitas tertentu yang

17 Bnd. Keener, And Marries Another viii-x.

18 Bnd. Osiek, Familienangelegenheiten 248; Martin, Blick 265

19 Bnd. Moxnes, Family 21; Gujarro, Family 57-59 
digunakan bersama, misalnya rumah tangga dua atau lebih saudara. ${ }^{20}$ Sampai tujuh puluh lima persen dari semua penduduk dianggapnya mendiami rumah kecil, yang hanya terdiri dari satu kamar; maka kebanyakan penduduk Galilea pada abad pertama tinggal serumah sebagai keluarga kecil, mungkin kira-kira empat orang saja.

Menurut hokum Romawi dan Helenis perceraian boleh dilakukan pada prinsipnya oleh kedua pihak, baik oleh seorang suami maupun oleh seorang istri (semula bahkan ayahnya). ${ }^{21}$ Perceraian sebagaimana pernikahan pada umumnya, dipandang sebagai hal pribadi.Keterlibatan dan persetujuan dari lembaga tertentu - baik dari pihak lembaga Negara maupun dari pihak lembaga agama - tidak diperlukan. ${ }^{22}$ Akan tetapi, surat resmi seharusnya dibuat. Cara perceraian sangat sederhana.Sesudah kehendak untuk bercerai dinyatakan, suami mengusir istrinya keluar dari rumahnya, atau istri sendiri memutuskan pergi dan meninggalkan suaminya. ${ }^{23}$ Jika demikian ia biasanya tidak berhak menuntut bagian warisan yang diberikan ayahnya kepada suami sebelum menikah, sebaliknya ia bahkan dapat diwajibkan untuk mengembalikan pemberian mahar, sedangkan suami yang menceraikan istrinya tidak kehilangan warisan. ${ }^{24}$ Kecuali istri diusir karena perzinaan, kepadanya diserahkan warisan ayahnya dan sebagian mahar sesuai dengan ketentuan kontrak pernikahan.Anak tetap bersama ayahnya.Menurut kebanyakan ahli, perceraian sangat sering terjadi, dan tidak ada sangsi agamais atau stigma moralis yang berhubungan dengan itu. Dalam ukiran yang ditemukan pada sebuah kubur dikatakan: "Jarang terdapat perkawinan yang langgeng, yaitu yang dicerai maut dan bukan dicerai hidup." 25

\section{Konsep Yahudi}

Unsur suku, marga, dan keluarga mendirikan struktur masyarakat yang bermakna untuk orang Israel.Istilah beyt ' $a b$, yang dapat diterjemahkan secara harafiah "rumah ayah", berarti "rumah tangga dibawah kuasa ayah sebagai kepalanya." 26 Pada umumnya kepentingan keluarga diidentikan dengan kepentingan ayah sebagai kepala keluarga. ${ }^{27}$ Dalam umat Yahudi, sama seperti dalam masyarakat Yunani dan Romawi dan Romawi, terdapat keyakinan bahwa emosi manusia harus dikendalikan. Instansi yang dianggap bermanfaat

\footnotetext{
20 Bnd. Guijarro, Family 59-60.

21 Bnd. Hallet, Women's Lives 21-24.

22 Bnd. Cancik-Lindemair, Ehe 254.

23 Bnd. Kroll, Erotik 84; Instone-Brewer, Divorce 190.

24 Bnd. Rousselle, Ursprung 132.

25 Napel, Jalan 141.

26 Bnd. Perdue, Household...., 246.

27 Bnd. Pressler, View...., 96.
} 
untuk melakukan pengendalian itu bukan akal budi, melainkan terutama pada Hukum Allah. ${ }^{28}$ Yang menjadi nyata, hak dan kewajiban antara laki-laki dan perempuan sepanjang sejarah bangsa Israel tidak dirumuskan secara seimbang.Apabila seksualitas manusia diatur, perempuan hamper selalu diperlakukan sebagai objek hukum karena kepentingan pertama-tama ayahnya dan kemudian suaminya. ${ }^{29}$ Sebelum menikah posisi seorang gadis adalah dibawah otoritas ayahnya, sesudah menikah, perempuan ditempatkan dibawah otoritas suaminya. ${ }^{30}$ Hukum-hukum yang demikian berlatarbelakangkan masyarakat yang strukturnya patriakhal. ${ }^{31}$ Kedudukan subordinat seorang istri kepada suaminya kelihatan dalam control ekonomis suami terhadap rumah tangga, dalam klaimnya terhadap seksualitas istrinya yang unilateral dan absolut dan dalam kuasanya yang unilateral untuk memprakarsai perkawinan dan perceraian. ${ }^{32}$

Orang Yahudi menerima perceraian sebagai fakta nyata.Perceraian ditangani secara rutin dan dianggap sebagai bagian biasa dari interaksi di dalam keluarga dan di antara keluarga. ${ }^{33}$ Ada beberapa teks di dalam Perjanjian Lama yang berlatar belakang mengisyaratkan adanya praktik perceraian (Im. 21:7,22:13; Yes.54:6; Yer.3:1). Ezra 10 menuntut perceraian jika ada pernikahan pernikahan campur.Namun, dalam Alkitab tidak ditemukan teks hukum yang mengatur secara spesifik dan sistematis hal perceraian. ${ }^{34}$ Yang ditemukan adalah satu teks yang mengatur perkara tertentu yang sangat khusus: Seorang istri yang pernah diceraikan dan kawin lagi, tidak boleh diterima kembali oleh suaminya yang pertama bahkan jika suaminya yang kedua telah meninggal (Ulangan 24:1-4). Teks aturan itu mensyaratkan adanya perceraian dengan cara yang sangat sederhana, yaitu dengan memberikan surat cerai kepada istrinya. ${ }^{35}$ Dengan ini hukum Yahudi mengijinkan suami - dan pada umumnya hanya suami. ${ }^{36}$ - menceraikan pasangannya asalkan melalui bentuk-bentuk ketentuan yang sah (Yesaya 50:1; Yeremia 3:8). Surat cerai adalah dokumen legal yang mencatat pemisahan dan dengan ini memungkinkan perempuan yang diceraikan masuk ke dalam pernikahan baru. ${ }^{37}$ Jadi, istri memang tidak dilindungi dalam pernikahan dari keputusan suami untuk menceraikannya, tetapi paling sedikit ia bebas untuk masuk ke dalam pernikahan baru. Adanya surat cerai mencegah dakwaan zina terhadapnya. Kemudian, halangan cerai terbesar adalah bahwa pada saat cerai

\footnotetext{
28 Bnd. Frymer-Kensky, Law..., 242.

29 Bnd. Pressler, View..., 43.

Ibid.,

Bnd. Thielicke, Ethics..., 105.

Bnd. Pressler, View..., 113.

Bnd. Collins, Marriage..., 115.

Bnd. Harington, Attitude..., 199.

Bnd. Barclay, Matius..., 256.

Bnd. Weder, Perspektive..., 176.

Bnd. Duty, Divorce.., 32.
} 
ketubbah harus diberikan oleh laki-laki kepada mantan istri, kecuali istri tersebut terbukti tidak setia. ${ }^{38}$ Jika pada Perjanjian Lama perempuan yang diceraikan tidak diterima kembali dalam keluarga asalnya, mereka sering menempuh nasib berat, antara lain mereka mungkin terpaksa menjual diri sebagai budak atau harus bekerja sebagai pelacur. ${ }^{39}$ Pada zaman Perjanjian Baru nasib perempuan yang diceraikan sangat tergantung pada ketentuan kettubah.

Seorang istri Yahudi pada umumnya tidak bisa menceraikan suaminya, yaitu secara resmi keluar dari perkawinan atas inisiatif sendiri.Namun, perkara-perkara yang demikian dibuktikan oleh papyri Elefantine dari abad kelima sebelum Masehi untuk keadaan di Mesir pada waktu itu. ${ }^{40}$ Dimana dibuktikan ada hak perempuan untuk memprakarsai perceraian.Pengaruhnya pada umat Yahudi di Palestina kurang jelas. Dalam tulisan Yosefus, perbuatan cerai dari pihak Salome, yang ia lakukan sesuai dengan adat istiadat Yunani, ditegur karena melangga Hukum Yahudi. ${ }^{41}$

\section{$\underline{\text { Analisis Historis Surat Markus 10:9 }}$}

"Karena itu, apa yang dipersatukan Allah, tidak boleh diceraikan manusia (Markus 10:9).”Markus seorang Kristen yang hidup pada abad ke-1 dan diyakini sebagai penulis Injil Markus.Di sejumlah bagian Alkitab namanya ditulis "Yohanes yang disebut juga Markus". 42 Lahir di Kirene pada abad 1 Masehi.Wafat di Alexandria 68 Masehi. ${ }^{43}$ Di Yerusalem ketika raja Herodes Agripa I pada tahun pertama pemerintahannya (41M) menyuruh menahan Petrus di penjara, seorang malaikat Tuhan membawa Petrus keluar dari penjara dengan ajaib.Petrus pertama-tama mengunjungi rumah Maria, ibu Yohanes yang disebut juga Markus. ${ }^{44}$ Bersama Paulus dan Barnabas berangkat dari Yerusalem kembali ke Antiokhia, setelah menyelesaikan tugas pelayanan mereka, mereka membawa Yohanes, yang disebut juga Markus (Kis. 12:25). Oleh karena disuruh Roh Kudus, Barnabas dan Saulus berangkat ke Seleukia, dan dari situ mereka berlayar ke Siprus. Setiba di Salamis mereka memberitakan firman Allah di dalam rumah-rumah ibadat orang Yahudi. Dan Yohanes (Markus) menyertai mereka sebagai pembantu mereka.Mereka mengelilingi pulau itu sampai ke Pafos (Kis.13:3-6). Di sana Paulus

\footnotetext{
38 Bnd. Isaksson, Marriage..., 44.

39 Bnd. Perdue, Family..., 195.

40 Lih. Bammel, Eherecht..., 96-97.

41 Bnd. Evans, Mark..., 85.

42 https://id.m.wikipedia.org/wiki/Markus

43 Ibid.,

44 Ibid.,
} 
membutakan mata Elimas dan membuat Sergius Paulus, gubernur pulau Siprus, percaya akan Injil Kristus (Kis.13:7-12).

\section{Penulis Surat Injil Markus}

Penulis Injil Markus adalah Markus, yang disebut juga Yohanes (Kis.12:12,25; 15:37), kemenakan Barnabas, rekan sekerja Paulus (Kol. 4:10) dan yang disebut Simon Petrus sebagai "anaknya", yaitu "anak rohani" atau murid terdekatnya (1 Pet. 5:13). Menurut catatan gereja mula-mula, Markus menulis Injilnya berdasarkan penuturan Petrus. Eusebius mengutip tulisan Papias (60-130), uskup Hierapolis, sekitar 120, demikian :Pernyataan paling dini tentang asal mula Injil ini, ialah yang diberikan oleh Papias. Markus, penterjemah Petrus, dengan teliti menuliskan semua yang diingatnya, baik ucapan maupun perbuatan Yesus, tapi tidak berurutan, sebab dia bukan pendengar langsung dan tidak ikut menyertai Yesus.

Jadi, penulis Injil Markus adalah Markus yang disebut juga Yohanes.

\section{Tanggal dan Tujuan Penulisan}

Injil Markus merupakan salah satu kitab pertama yang dituliskan sekitar tahun 57-59. ${ }^{45}$ Jika Injil Matius secara garis besar sepertinya ditujukan kepada bangsa Romawi, juga kepada orang non-Yahudi.Markus menulis sebagai seorang pendeta kepada orang Kristen yang sudah pernah mendengar dan mempercayai Injil (Roma 1:8).Ia berusaha menyajikan biografi Yesus Kristus sebagai Hamba Tuhan dan Juruselamat dunia sehingga iman mereka diperkuat ditengah-tengah penganiayaan yang hebat, termasuk mengajarkan kepada mereka makna menjadi seorang murid. ${ }^{46}$ Pada tahun 60 -an $\mathrm{M}$, orang percaya diperlakukan secara kejam oleh masyarakat dan banyak dibunuh dibawah pemerintahan kaisar Nero.Menurut tradisi, di antara para syahid Kristen di Roma itu terdapat Rasul Petrus dan Rasul Paulus.Selaku salah seorang pemimpin gereja di Roma, Yohanes Markus digerakkan oleh Roh Kudus untuk menulis Injil ini sebagai suatu antisipasi yang bersifat nubuat atau tanggapan penggembalaan terhadap masa penganiayaan ini.Tujuannya ialah memperkuat dasar iman dalam orang percaya di Roma, dan jikalau diperlukan, mendorong mereka untuk dengan setia menderita demi Injil, dengan memperhadapkan kepada mereka kehidupan, penderitaan, kematian serta kebangkitan Yesus. $^{47}$

\footnotetext{
45 www.gotquestions.org/indonesia/kitab-injil-Markus

46 www.gotquestions.org/indonesia/kitab-injil-Markus

47 https://alkitab.sabda.org/article.php?id=173
} 
Dalam suatu kisah yang bergerak dengan cepat, Markus memperkenalkan Yesus sebagai Putra Allah dan Mesias, hamba yang menderita. Titik yang menentukan dalam kitab ini adalah episode di Kaisarea Filipi, yang disusul oleh peristiwa pemuliaan Yesus (Mrk.8: 27-9:10), ketika identitas dan misi penderitaan Yesus dinyatakan dengan jelas kepada kedua belas murid-Nya. Bagian pertama kitab Injil ini memusatkan perhatian terutama kepada mujizat luar biasa yang dilakukan Yesus dan pada kuasaNya atas penyakit dan setan-setan sebagai tanda bahwa Kerajaan Allah sudah dekat. Akan tetapi, di Kaisarea Filipi itu Yesus memberitahukan dengan terus terang kepada para murid bahwa Dia harus "menanggung banyak penderitaan dan ditolak oleh tua-tua, imam-imam kepala dan ahli-ahli Taurat, lalu dibunuh dan bangkit sesudah tiga hari” (Mrk.8:31). Banyak ayat dalam kitab ini menyebut penderitaan sebagai harga kemuridan (Mrk. 3:21-22,30; 8:34-38; 10:33$34,35 ; 13: 8,11-13)$. Namun setelah mereka menderita karena Dia maka Allah akan menyatakan bahwa ia berkenan kepada mereka, sebagaimana di tunjukkan dalam kebangkitan Yesus. ${ }^{48}$

Jadi, Injil Markus ditulis sekitar tahun 57-59 Masehi. Dan Injil Markus mempunyai tujuan menyajikan biografi Yesus Kristus sebagai Hamba Tuhan dan Juruselamat dunia sehingga iman mereka diperkuat ditengah-tengah penganiayaan yang hebat, termasuk mengajarkan kepada mereka makna menjadi seorang murid.

\section{Analisa Konteks}

Markus 8:27-10:52 menceritakan perjalanan Yesus dari daerah Kaisarea Filipi (Mrk.8:27) melewati Galilea/Kapernaum (Mrk.9:30,33) dan lembah Sungai Yordan (Mrk.10:1) ke Yerikho (Mrk.10:46) menuju Yerusalem (Mrk.10:32,11:1). ${ }^{49}$ Pada perjalanan itu Yesus mulai mengajar muridNya (Mrk.8:31) bahwa sesuai dengan kehendak Allah Ia akan diserahkan, menderita, meninggal, dan dibangkitkan. Bagian Injil Markus ini diberi struktur khas dengan adanya tiga pemberitahuan tentang peristiwa-peristiwa tersebut yang akan terjadi nanti di Yerusalem (Mrk.8:31-32a, 9:30-31, 10:3234). ${ }^{50}$ Pemberitahuan itu masing-masing diikuti oleh catatan tentang kekurangpahaman murid-Nya (Mrk.8:32b, 9:32-34, 10:35-37) dan pengajaran Yesus kepada mereka tentang cara mengikutiNya dan tentang hubungan kemuridan yang benar diantara mereka (Mrk.8:33-9:1, 10:38-45). ${ }^{51}$

Teks Markus 10:1-12 tentang isu perceraian berada di antara pemberitahuan yang kedua (Mrk.9:30-32) dan yang ketiga (Mrk.10: 32-34). Topik-topik lain yang merupakan bingkai di sekitar nas itu mencakup

48 https://alkitab.sabda.org/article.php?id=173

49 Bnd. Pesch, Markusevangelium 121.

50 Bnd. Dschulnigg, Markusevangelium..., 267.

51 Bnd. Hermon, Mark's Jesus..., 280. 
perhatian Yesus kepada anak-anak dan "yang kecil" (Mrk.9:36-37,42 dan 10:13-16), serta tema pahala di surga, pintu masuk ke dalam kehidupan dan Kerajaan Allah (Mrk.9:41-48 dan 10:13-31) ${ }^{52}$ Nas sebelum teks kita berbicara tentang kewaspadaan dan penolakan terhadap godaan (Mrk.9:42-50); ayat ini diakhiri dengan catatan tentang pentingnya garam, dan dalam ayat terakhirnya ditemukan perintah Yesus: "Milikilah garam, di dalam dirimu, dan berdamailah satu dengan yang lain." (Mrk.9:50c). Nas tentang seorang kaya (Mrk.10:17-22), yang sesudah nas kita, mengutip secara eksplisit perintah "jangan berzina" dari Dasa Titah sebagai kewajiban yang harus dipenuhi (Mrk.10:19) untuk memperoleh hidup yang kekal. Berdasarkan konteks literati situ, larangan Yesus supaya jangan bercerai dapat dimengerti sebagai satu aspek cara mengikuti-Nya dengan benar, yaitu termasuk mentaati Hukum Allah, bertahan dalam kesusahan/godaan dan bersedia untuk menerima penderitaan. ${ }^{53}$

Perikop ini terdiri atas dua bagian tematis (ayat 2-9 dan 10-12), didahului oleh sebuah pendahuluan dalam ayat pertama.Karena ayat 10-12 kita anggap dikarang oleh penulis Injil Markus berdasarkan tradisi perkataan sejarah, maka pada dasarnya lebih tua daripada ayat yang sekarang lebih dulu. Namun pembahasan ayat 1-9 akan ditemukan tradisi jemaat mula-mula.

Kata (synedseuken) dalam ayat 9 sebenarnya berarti menghubungkan bersama $($ syn = bersama dengan $)$ di bawah satu kuk $($ desugos $=k u k)$. Hubungan suami istri diibaratkan seperti hubungan melalui kuk pada dua leher kerbau ketika membajak sawah, yang dimaksudkan adalah hubungan yang dibuat untuk bekerja dan menanggung beban bersama.Oleh karena itu, terjemahan dihubungkan (kedua kerbau dalam gambaran tetap dua) terasa lebih tepat daripada dipersatukan. Dalam teks Yunani terdapat larangan (me khoridseto) yang sebenarnya aktif dan berarti janganlah (manusia) memisahkan, tetapi di dalam teks Indonesia diterjemahkan tidak boleh diceraikan (manusia). Sesuai dengan konteks kalimat, terjemahan pasif masuk akan yaitu janganlah dipisahkan (oleh manusia). Namun, terjemahan Indonesia agaknya mengurangi penekanan yang hendak ditunjukkan kalimat perintah (imperative orang ketiga tunggal) dalam teks asli.

Ayat 9 adalah hasil argumentasi Yesus yang berdasarkan Hukum Taurat. Kesatuan suami-istri itu sebagai yang dinginkan oleh Allah sendiri sebagai Sang Pencipta, tidak boleh dipisahkan oleh manusia. Manusia tidak boleh meruntuhkan pekerjaan Allah yang telah diatur dengan baik sejak semula. Jawaban Yesus atas pertanyaan orang Farisi pada ayat 2 "apakah seorang suami diperbolehkan menceraikan istri" adalah "tidak" (baik untuk seorang suami maupun seorang istri) ${ }^{54}$ Ia merangkumkan buah pikiran-Nya

\footnotetext{
52 Bnd. Sanger, Schriftauslegung..., 31.

53 Bnd. Anderson,Marks..., 242.

54 Bnd. Zimmerman, Zitation...,95.
} 
dengan mengutarakan perintah: "Apa yang telah dihubungkan Allah janganlah dipisahkan oleh manusia".

Dalam Markus 10:2-9 perceraian secara absolute dilarang dengan alas an bahwa Allah sendirilah yang telah menghubungkan (ayat 9), bahkan mempersatukan kedua mempelai. ${ }^{55}$ Yesus mengatakan bahwa pernikahan seharusnya jangan dibubarkan, tetapi ia tidak mengatakan bahwa pernikahan tidak mungkin dibubarkan. ${ }^{56}$ Penulis kurang yakin apakah dorongan seksual antara laki-laki dan perempuan benar-benar dapat dikatakan selalu mengantar kedua pasangan ke dalam kesatuan yang utuh dan stabil.

Dorongan seksual (kepada pihak ketiga) justru juga dapat menghancurkan hubungan yang ada di antara seorang suami dan seorang istri. Kestabilan hubungan suami istri berdasarkan banyak factor lain. Logika kesimpulan Yesus dapat diragukan bahwa karena Allah menciptakan manusia sebagai mahkluk berseksualitas (tentang manusia sebagai keluarga/genus), Ia yang sebenarnya menghubungkan tiap-tiap pasangan secara konkret (tentang manusia sebagai dua individu). ${ }^{57}$

Jadi, setelah menganalisa konteks maka didapati pandangan Yesus tentang perceraian adalah "percerain dilarang/tidak diperbolehkan".

\section{$\underline{\text { Alasan Tidak Boleh Bercerai }}$}

Alasan mengapa suami dan istri tidak boleh bercerai adalah karena apa yang telah dipersatukan Allah tidak boleh diceraikan manusia, seperti yang terdapat dalam Markus 10:9. Membandingkan ucapan Tuhan Yesus dalam Mat 5:32 dengan Mat 19:3-12; Mrk. 10: 2-12; Luk. 16:18 nampak bahwa Dia mencap perceraian dan kawin kembali sebagai perzinaan. ${ }^{58}$ Tapi tidak dikatakan bahwa manusia tidak boleh menceraikan apa yang telah dipersatukan Allah. Kedua bagian di atas mengatakan bahwa hanya percabulan atau persundalanlah yang boleh dijadikan dasar untuk menceraikan istri, walaupun ucapan itu tidak ada dalam Injil Markus dan Lukas. ${ }^{59}$ Percabulan dan persundalan disini biasanya dianggap sama dengan perzinaan; dan sejalan dengan itu tingkah laku umat Israel sebagai istri Yahweh dicap sebagai perzinaan (Yer. 3:2-3; Yeh. 23:43); istri yang tidak setia dituduh melakukan zina dalam percabulan (1 Kor. 7:2).

Alasan mengapa 'terkecuali' dalam Injil Markus dan Lukas mungkin adalah karena orang Yahudi, Romawi maupun Yunani menyangsikan bahwa perzinaan dapat dijadikan dasar untuk perceraian, sementara para penginjil

\footnotetext{
55 Bnd. Via, Ethics..., 112.

56 Bnd. Kenner, And Marries Another..., 41.

57 Bnd. Van Iersel, Mark 318-320.

58 Bnd. Ensiklopedi Alkitab Masa Kini Jilid 2, 157

59 Ibid.,
} 
menganggap zina hukum yang teguh. ${ }^{60}$ Sejalan dengan itu dalam Roma 7:1-3 sambil merujuk ke hukum Yahudi dan Romawi, rasul Paulus tidak menyebut kemungkinan perceraian karena perzinaan, padahal hukum kedua bangsa itu memuatnya. Teori-teori ini mengemukakan makna lain dari ucapan Tuhan Yesus itu. Sebagian mengenakan percabulan kepada kelakuan pra-nikah, yang diketahui oleh suami sesudah menikah. Yang lain berpendapat kedua belah pihak mengetahui kemudian bahwa mereka dalam tali kekerabatan yang terlarang menikah.Tapi yang terakhir ini terlalu ganjil menjadi dasar kekecualian khusus dalam ucapan Tuhan Yesus itu.Ada golongan yang mengartikan kata-kata itu menghalalkan perceraian, tetapi tidak menghalalkan kawin kembali. Namun sukar sekali menarik kesimpulan bahwa Matius 19:9 tidak mengijinkan menikah lagi; dan dalam kehidupan orang Yahudi tidak terdapat perceraian tanpa boleh menikah lagi.

Ada yang meragukan keaslian Markus 10:12, karena biasanya perempuan Yahudi tidak boleh menceraikan suaminya. Tetapi seorang istri boleh mengadu ke pengadilan tentang perlakuan suaminya terhadap dia, dan pengadilan dapat memaksa suaminya menceraikan. ${ }^{61}$ Lagi pula Tuhan Yesus mungkin mengingat hukum Yunani dan Romawi, dan menurut kedua hukum itu istri boleh menceraikan suaminya, seperti Herodias menceraikan suaminya. Ada pendapat yang teguh pada golongan Protestan dan Katolik bahwa 1 Kor 7:10-16 mengemukakan dasar yang lain untuk perceraian. Di sini rasul Paulus mengulangi ajaran yang diberikan Tuhan Yesus, tatkala Dia masih di bumi, lalu dengan pimpinan Roh Kudus, memberikan ajaran yang melebihi apa yang diajarkan Tuhan Yesus, sebab situasi baru sudah timbul. Jika dalam pernikahan non-Kristen satu pihak bertobat kepada Kristus, yang bertobat itu tidak boleh meninggalkan teman hidupnya.Tetapi dipihak yang tidak bertobat itu mendesak perceraian, maka dalam hal yang demikian saudara atau saudari tidak terikat.Kalimat terakhir ini tak mungkin berarti bahwa mereka bebas bercerai, tetapi harus berarti bahwa mereka boleh menikah lagi.Dasar terakhir ini, yang sekilas pandang pengenaannya terbatas, terkenal sebagai keluwesan Paulus. ${ }^{62}$

\section{Dampak Perceraian}

Perceraian orang tua dapat menyisakan luka dalam benak anak. Bahkan, luka yang dialami anak mungkin saja akan terus dibawanya hingga dewasa. Dampak yang mungkin terjadi pada setiap anak bisa berbeda-beda, tergantung dari usia anak pada saat orang tua bercerai, kondisi perceraian, serta kepribadian anak tersebut. ${ }^{63}$ Perceraian dapat menciptakan gejolak emosi bagi

60 Ibid.

${ }^{61}$ Bnd. J.D.Douglas, Ensiklopedi Alkitab Masa Kini Jilid 2, 157.

62 Bnd. J.D.Douglas, Ensiklopedi Alkitab Masa Kini Jilid 2, 157.

${ }^{63} \mathrm{https} / / / \mathrm{www}$.alodokter.com/hilangkan-ego-ini-dampak-perceraian-terhadap-anak 
seluruh keluarga dan juga berdampak besar pada sisi psikologis anak.Pada anak, situasi perceraian orang tua dapat sangat menakutkan, membingungkan, dan membuat frustrasi.Anak-anak kecil sering berjuang untuk memahami mengapa mereka harus pergi meninggalkan salah satu orang tuanya.Anak juga mungkin khawatir jika perpisahan ini membuat orang tua berhenti saling menyayangi dan mereka tidak lagi menyayangi si anak. ${ }^{64}$

Perceraian juga menimbulkan dampak rasa bersalah mendalam. Rasa bersalah adalah guilty feelings ada dua macam, yaitu: objective guilt dan subjective guilt. Objective guilt adalah rasa bersalah karena pelanggaran terhadap hukum yang berlaku di masyarakat.Rasa bersalah karena pelanggaran terhadap hukum yang tidak tertulis yang berlaku di masyarakat. Rasa bersalah karena pelanggaran terhadap kesadaran akan kebenaran yang ada dalam hati yang bersangkutan, misalnya orangtua memukul anaknya tanpa alasan yang benar. Rasa bersalah karena pelanggaran terhadap hukum-hukum Allah, seperti tingkah laku yang diberikan Alkitab, jika dilanggar akan menghasilkan rasa bersalah walaupun yang bersangkutan tidak merasakan guilty. ${ }^{65}$

\section{$\underline{\text { Alasan Tidak Boleh Bercerai }}$}

Pernikahan adalah tahap kehidupan yang dalamnya laki-laki dan perempuan boleh hidup bersama-sama dan menikmati seksual secara sah.Perzinahan dan persundalan adalah hubungan seksual yang tidak diakui oleh masyarakat sebagai konstitusi pernikahan.Definisi ini memperlihatkan bahwa poligami dalam Perjanjian Lama tidak dianggap salah, karena merupakan konstitusi pernikahan yang sah diakui oleh masyarakat, walaupun umumnya terbukti tidak bijaksana. ${ }^{66}$

Pernikahan merupakan pertemuan masing-masing pihak yang sepakat untuk siap berubah ke arah yang lebih baik. Maka pertemuan tersebut merupakan kesempatan untuk belajar berkembang bersama, dan mereka mencari dan berangkat dari realita yang ada.Dalam pertemuan itu prinsip "berjalan bersama" patut mendapat peran penting.Di sini tampak masingmasing pihak saling membina. ${ }^{67}$

Jadi, alasan tidak boleh bercerai adalah karena pernikahan adalah lembaga yang diciptakan Allah sendiri. Dan menurut Markus 10:9 apa yang terlah dipersatukan Allah janganlah dipisahkan oleh manusia.

64 https://beritagar.id/artikel/gaya-hidup/dampak-perceraian-pada-psikologis-anak

65 Bnd. Jason Lase, Konseling Pastoral, 131.

66 Bnd. J.D.Douglas, Ensiklopedi Alkitab Masa Kini Jilid 2, 154.

67 Bnd. Sularso Sopater, Studi Kasus Pastoral III, 74. 


\section{Sikap Etis Kristen Terhadap Perceraian}

Untuk diri sendiri - menimbang pemahaman tentang perceraian dari Markus 10:9 dan berdasarkan analisa konteks mengenai ayat ini maka sikap etis yang bisa penulis ambil untuk diri sendiri adalah tidak boleh cerai sampai maut memisahkan.

Untuk orang lain - mengumandangkan akan sakralnya pernikahan khususnya bahwa orang percaya tidak boleh melakukan perceraian. Juga memberikan bimbingan kepada orang yang diambang perceraian.

Untuk orang yang telah bercerai - memberikan kekuatan, penghiburan, pendampingan untuk tetap dalam jalurnya Tuhan, yakni terjadinya mujizat untuk pemulihan kembali dalam pernikahan Kristen.

Dibutuhkan komunikasi yang baik terhadap semua kebenaran ini.Komunikasi bukan sekedar kemampuan berbicara.Bukan pula sekedar berkata pada waktu yang tepat.Anda dapat melakukan semua perkara itu namun belum berkomunikasi. ${ }^{68}$

\section{SIMPULAN}

Semua orang percaya harus memahami dan meyakini bahwa Allah sumber kasih (Roma 5:8). Adalah penting untuk setiap manusia memahami, dan mengalami kasih Allah dalam pengalaman nyata sehari-hari (Ibr. 2:9). Allah sebagai desainer pernikahan, telah mendesain pernikahan sebagai satu lembaga ciptaan Allah yang tertua dalam dunia ini. ${ }^{69}$ Sebelum ada satu bangsa, kerajaan, bahkan gereja, Allah terlebih dahulu menciptakan satu unit keluarga. Kasih dalam hubungan Adam dan Hawa begitu harmonis meniktmati kasih Tuhan di dalam Taman Eden. Pernikahan adalah suatu hal yang unik, juga indah dan kudus.Alkitab memberikan gambaran hubungan suami istri seperti hubungan Kristus sebagai mempelai laki-laki dengan orang-orang percaya sebagai mempelai perempuan (Efesus 5:22-23).

Kegagalan hubungan suami-istri yang diikuti perceraian adalah salah satu dari sekian banyak realitas yang terjadi dalam kehidupan manusia. Yang penting membedakan antara kedua fenomena itu: Keinginan seorang istri atau seorang suami untuk bercerai adalah akibat dari kegagalan hubungan kasih. ${ }^{70}$ Kasih berperan penting dalam kelangsungan hidup pernikahan karena kasih menutupi banyak sekali dosa (1 Pet.4:8). Karena kasih juga membuat seseorang rela berkorban (Ams.17:17), bahkan memberikan nyawanya. Perceraian bukanlah jalan akhir untuk penyelesaian masalah dalam pernikahan.

68 Bnd. David Hocking, Rahasia Keberhasilan Seorang Pemimpin, 42.

69 Bnd. Jaliaman Sinaga, Tujuh Pilar Pernikahan, 1.

70 Bnd. Ruth Schrafer, Bercerai Boleh Boleh Atau Tidak?, 1 
Masih ada mujizat bagi orang yang percaya kepadaNya. Seungguhnya tangan Tuhan tidak kurang panjang untuk menyelamatkan dan pendengaranNya tidak kurang tajam untuk mendengar (Yes. 59:1). Hubungan suami-istri yang harmonis sangat bergantung kepada pengertian kedudukan suami dan istri menurut Alkitab, dan bagaimana baik suami maupun istri menempatkan diri sesuai dengan pengertian itu. ${ }^{71}$

\section{DAFTAR PUSTAKA}

Anderson, Hugh.

1976 Marks

Bammel, Ernst.

1970 Eherecht

Douglas, J.D.

1995 Ensiklopedi Alkitab Masa Kini Jilid II. Jakarta: Yayasan Komunikasi Bina Kasih

Dschulnigg, Peter.

2007 Markusevangelium. Stuttgart: Kohlhammer.

Evans, Craig.

2001 Mark

Hocking, D.

1993 Rahasia Keberhasilan Seorang Pemimpin. Yogyakarta: Yayasan Andi

Herron, Robert.

1982 Mark's Jesus

Keener, Craig.

1992 And Maries Another.

Lase, J.

2009 Konseling Pastoral. Bandung: Jurnal Info Media

Pesch, Rudolf.

2000 Markusevangelium

71 Bnd. D.Scheunemann, Romantika Kehidupan Suami-Istri, 13. 
Sanger, Dieter.

1999 Schriftauslegung

Scheunemann, D.

1987 Romantika Kehidupan Suami-Istri. Malang: Gandum Mas

Sinaga, J.

2004 Tujuh Pilar Pernikahan. Jakarta: Divisi Pengajaran GBI Jl Gatot Subroto

Schafer, R.

2017 Bercerai Boleh Atau Tidak?. Jakarta: Gunung Mulia

Sopater, S.

1990 Studi Kasus Pastoral III. Jakarta: Gunung Mulia

Via, Dan O.,

1985 The Ethics of Mark's Gospel. Philadelphia: Fortress.

Van Iersel.

1998 Sieffield: Academic Press.

Zimmerman, ttZitation

\section{Sumber Internet:}

https://www.alodokter.com/hilangkan-ego-ini-dampak-perceraian-terhadapanak

https://beritagar.id/artikel/gaya-hidup/dampak-perceraian-pada-psikologisanak

www.gotquestions.org/indonesia/kitab-injil-Markus

https://alkitab.sabda.org/article.php?id=173

https://id.m.wikipedia.org/wiki/Markus 